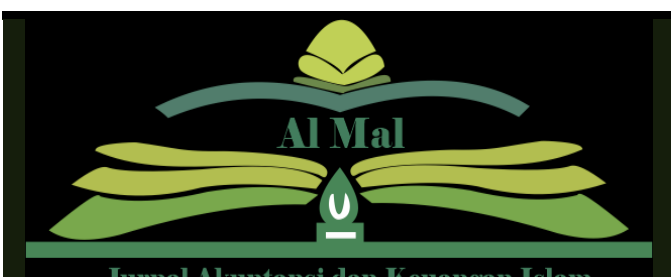

Jurnal Akuntansi dan Keuangan Islam

Al-Mal: JurnalAkuntansi dan Keuangan Islam E-ISSN: 2715-9477, P-ISSN: 2751-954X

Volume 03 Issue 01, 21 Januari 2022 Journal Page is available to:

http:// ejournal.radenintan.ac.id/index.php/al-mal/index

\title{
Pengaruh Kualitas Aktiva Produktif, Dana Pihak Ketiga Dan Liabilitas Terhadap Earning After Tax Pada Bank Syariah Bukopin
}

\author{
Musdalifah $^{1}$, Nurlaila², Laylan Syafina ${ }^{3}$
}

$1^{*}, 2,3$, Departement of Economics, Faculty of Economics and Business Universitas Islam Negeri Sumatera Utara Medan, , Indonesia

\begin{tabular}{l}
\hline \multicolumn{1}{c}{ ARTICLE INFO } \\
\hline Article history: \\
Received 18-01-2022 \\
Revised 20-01-2022 \\
Accepted 21-01-2022 \\
Available 21-01-2022 \\
Revised (1) 24-07-2022 \\
Accepted 31-07-2022 \\
Revised Available 01-08-2022 \\
Kata Kunci: \\
Earning After Tax, Kualitas Aktiva \\
Produktif, Dana Pihak Ketiga, dan \\
Liabilitas
\end{tabular}

Paper type: Research paper

Please cite this article: Musdalifah. Nurlaila., \& Safina, L. E. "Pengaruh kualitas aktiva produktif, dana pihak ketiga dan liabilitas terhadap Earning After Tax pada Bank Syari'ah Bukopin Periode 2018-2020" Al-Mal: Jurnal Akuntansi dan Keuangan Islam [ONLINE], Volume 03 Number 01 (Januari 21, 2022)

Cite this document:

Al-Mal 2th edition

*Corresponding author

e-mail: musdaaliifah@gmail.com

\begin{abstract}
ABSTRAK
Tujuan Penelitian ini untuk mengetahui pengaruh dari variabel Kualitas Aktiva Produktif, Dana Pihak Ketiga, dan Liabilitas terhadap Earning After Tax. Sumber data sekunder dengan pendekatan kuantitatif serta studi dokumentasi dengan mengambil idata yang telah dipublikasi oleh Bank Bukopin Syariah. Teknis analisis data dalam penelitian ini menggunakan uji Regresi Linear Berganda, Uji Parsial, Uji Simultan, serta Uji Determinasi dengan bantuan Eviews 9. Hasil uji parsial (uji t) dalam penelitian ini menunjukkan variabel Kualitas Aktiva Produktif berpengaruh secara negatif dan signifikan terhadap Earning After Tax. Hasil Uji Parsial untuk variabel Dana Pihak Ketiga tidak berpengaruh terhadap Earning After Tax. Secara parsial variabel Liabilitas berpengaruh secara negatif dan signifikan terhadap Earning After Tax. Secara simultan variabel Kualitas Aktiva Produktif, Dana Pihak Ketiga, dan Liabilitas berpengaruh signifikan terhadap Earning After Tax. Keterbatasan penelitian ini pada objek pengamatan penelitian terfocus pada Bank Syari'ah Bukopin sehingga membuka peluang untuk peneliti selanjutnya menambahkan objek yang lebih luas. Implikasi pada penelitian ini yaitu Earning After Tax yang mengalami peningkatakan, sesuai dengan penyebabnya yaitu jika makin tinggi laba maka suatu perusahaan akan makin fleksibel pula untuk melaksanakan setiap proses kegiatan yang ada di dalam perusahaan tersebut.
\end{abstract}


ABSTRACT: The purpose of this study was to determine the effect of the Earning Asset Quality, Third Party Funds, and Liability variables on Earning iAfter Tax. Secondary data sources with a quantitative approach as well as documentation studies by taking data that has been published by Bank Bukopin Syariah. Technical analysis of the data in this study using Multiple Linear Regression Test, Partial Test, Simultaneous Test, and Test of Determination with the help of Eviews 9. The results of the partial test ( $t$ test) in this study indicate that the Earning Asset Quality variable has a negative and significant effect on Earning After Tax. Partial Test Results for Third Party Fund variables have no effect on Earning After Tax. Partially, the Liability variable has a negative and significant effect on Profit After Tax. Simultaneously, the variables of Earning Assets Quality, Third Party Funds, and Liabilities have a significant effect on Earning After Tax. The limitation of this research is that the object of observation is focused on the Bukopin Syari'ah Bank so that it opens up opportunities for further researchers to add wider objects. The implication of this study is that Earning After Tax has increased, according to the cause, namely the higher the profit, the more flexible a company will be to carry out every process of activities that exist within the company.

\section{Keyword: Earning After Tax, Earning Asset Quality, Third Party Funds, and Liabilities}

\section{PENDAHULUAN}

Kegiatan sistem perniagaan pada suatu Negara tak lepas dari lembaga keuangan salah satunya perbankan Bank merupakan suatu lembaga yang memiliki aktivitas untuk menggabungkan dana dari masyarakat kepada masyarakat yang deficit serta memberikan berbagai jasa yang ada diperbankan lainnya.

Bank dalam melakukan kegiatannya dalam menggunakan dana merupakan salah satu usaha bank untuk meningkatkan kualitas aset produktif. Pengelolaan dana yang dilakukan dalam asset produktif sebagai salah satu sumber pendapatan yang diguankaan untuk biaya seluruh kegiatan operasional diantaranya distribusi bagi hasil. Piutang dan qardh adalah asset produktif pada bentuk pembiyaan yang mana bisa dinilai dari ikegiatan iusaha yang dilakukan, kondisi keuangan yang ditekankan pada arus kas nasabah, serta kemampuan untuk melakukan pembayaran.

Hal penting pada dana bank adalah Dana pihak ketiga di mana menjadi standar perbandingan atau patokan bagi bank terkait kemampuan menjalankan 
aktivitasnya, dana ini penting karena sumber dana ini dapat dikatakan mudah didapatkan dan tersedia di kalangan masyarakat. Pihak bank memberikan penawaran terkait berbagai jenis simpanan untuk para nasabah sesuai dengan tujuan dari tiap-tiap jenis simpanan itu sendiri. Pilihan yang telah diberikan pasti mempunyai suatu pertimbangan dan adanya harapan untuk memperoleh hasil yang diinginkan seperti pencapaian keuntungan, kemudahan serta keamanan uang dan semuanya. Untuk kegiatan penghimpun dana yang berupa simpanan dibagi menjadi 3 jenis yaitu simpanan tabungan, deposito, serta giro.

Liabilitas atau hutang didalam PSAK dikenal dengan istilah kewajiban, biasanya dikenal dengan kewajiban perusahaan untuk membayar kepada perusahaan lainnya. Liabilitas merupakan suatu hutang yang diselesaikan melalui arus kas keluar yang diperoleh dari sumber daya perusahaan yang sifatnya ekonomi. Liabitas yang digunakan perusahaan bertujuan untuk imenambah modal yang dipakai untuk membiayai jalannya operasional perusahaan.

Earning After Tax yaitu laba bersih setelah pajak yang dapat dilihat dari total seluruh laba yang dihasilkan dari pendapatan dikurang dengan beban yang telah dikurangi pajak. Earning After Tax (EAT) dipengaruhi oleh beberapa faktor yaitu ukuran laba bersih setelah pajak yaitu kualitas asset produktif, pengelolaan beban-beban perusahaan dan pajak yang diterima. Semakin meningkat kualitas asset produktif, dana pihak ketiga, liabilitas yang termasuk dalam kategori lancar, seharusnya dapat meningkatkan laba perusahaan.

Penelitian terdahulu telah membuktikan bahwa kualitas asset produktif, dana pihak ketiga serta liabilitas yang meningkat serta perhatian serta kesadaran masyarakat juga semakin besar akan membuat suatu lembaga keuangan memperoleh keuantungan bagi perusahaan juga dengan laba yang akan diperoleh oleh instansi tersebut. Kualitas aset produktif menjadi salah satu faktor pendukung dalam memperoleh laba yang akan dihasilkan. 
Perolehan laba bank syariah juga dipengaruhi oleh penempatan dana disisi aset dilihat produktif atau tidak.

Dari latar belakang yang telah dijelaskan penulis, maka rumusan masalah pada peneltian ini adalah Apakah Kualitas Aktiva Produktif berpengaruh terhadap Earning After Tax Pada Bank Syariah Bukopin Periode 2018-2020, Apakah Dana Pihak Ketiga berpengaruh terhadap Earning After Tax Pada Bank Syariah Bukopin Periode 2018-2020, Apakah Liabilitas berpengaruh terhadap Earning After Tax Pada Bank Syariah Bukopin Periode 2018-2020, Apakah Kualitas Aktiva Produktif, Dana Pihak Ketiga, Dan Liabilitas berpengaruh terhadap Earning After Tax Pada Bank Syariah Bukopin Periode 2018-2020.

Berdasarkan rumusan masalah diatas, maka tujuan dari penelitian ini adalah untuk mengetahui pengaruh Kualitas Aktiva Produktif terhadap Earning After Tax Pada Bank Syariah Bukopin Periode 2018-2020, untuk mengetahui pengaruh Dana Pihak Ketiga terhadap Earning After Tax Pada Bank Syariah Bukopin Periode 2018-2020, untuk mengetahui pengaruh Liabilitas terhadap Earning After Tax Pada Bank Syariah Bukopin Periode 20182020, untuk mengetahui pengaruh Kualitas Aktiva Produktif, Dana Pihak Ketiga, dan Liabilitas terhadap Earning After Tax Pada Bank Syariah Bukopin Periode 2018-2020. Jenis penelitian yang digunakan adalah penelitian kuantitatif yang bersifat asosiatif dengan metode data panel. Sumber data pada penelitian ini yaitu data sekunder berupa laporan keuangan bulanan pada bank syariah bukopin yang dipublikasi pada situs website resmi perusahaan (www.syariahbukopin.go.id).

\section{Earning After Tax}

Earning after tax (EAT) merupakan laba operasi perusahaan setelah dikurang pajak penghasilan (Sarmo et al., 2019). Earning after tax dikenal juga dengan laba bersih sebelum pajak adalah penghasilan yang diterima suatu bank dalam periode waktu tertentu, melalui perhitungan total pendapatan mengurangkannya dengan biaya sesudah pajak (Lailatus et al., 2020). Laba atau 
Ar-Ribh (dalam Bahasa Arab) yang artinya pertumbuhan dalam perdagangan. Didalam almu'jam al Iqtisad al - islami disebut bahwa keuntungan adalah tambahan dari pendapatan pada suatu proses dagang. Dalam bahasa Arab ribh artinya jual beli serta rabihah artinya hasil yang didapat.

Definisi laba pada ayat di atas yaitu kelebihan atau penambahan pada modal pokok yang didapat dari kegiatan dagang. Pada tiap-tiap bank melangsungkan proses transaksi setidaknya mengharapkan memperoleh laba yang maksimal.

\section{Kualitas Aktiva Produktif}

Aktiva Produktif merupakan kegiatan penanaman modal oleh suatu lembaga yang mempunyai tujuan untuk mendapatkan penghasilan. Aktiva produktif pada bank berupa pemberian kredit yang diberikan kepada masyarakat. Aktiva produktif merupakan penggunaan, penanaman, dan penempatan dana bank yang dapat mendatangkan penghasilan bagi sebuah bank yang sesuai dengan fungsinya (Rohim et al., 2017). Kualitas aktiva produktif menjadi salah satu acuan ukuran pada kinerja suatu perbankan dan harus sejalan dengan ketentuan syariah. Semakin bagus kualitas aktiva produktif maka akan meningkatkan profitabilitas sehingga bank dapat tumbuh secara baik (Dewi \& Wisadha, 2015). Penilaian kualitas aktiva produktif dilihat dari rasio Penyisihan Penghapusan Aktiva Produktif (PPAP) terhadap aktiva produktif yang dimiliki bank. PPAP merupakan cadangan penyisihan dari aktiva produktif yang dibentuk untuk menutup resiko kerugian dari penanaman dana (Sunarto \& Supriati, 2017). Manajemen aset merupakan pelaksanaan atau mengelola dana dalam bentuk aset seperti menyalurkan dana tersebut ke bentuk aset yang bisa mendapatkan hasil serta juga tidak dapat mendapatkan hasil kepada bank.

Dana yang digunakan oleh bank yang bersifat aset merupakan penanaman dana bank dalam bentuk rupiah ataupun valas untuk mendapat pendapatan yang berupa pembiayaan, surat berharga berbasis syariah, penempatan Bank Indonesia dan pemerintah, pembelian dan 
penjualan kembali surat berharga yang telah dianjikan, transaksi rekening administrative, tagihan deveratif, penyertaan, dan pelayanan dana lain yang sama seperti yang disebutkan. Semakin besar nilai yang ditunjukkan oleh kualitas aktiva produktif, maka semakin besar pula bank harus mencadangkan keuntungan yang diperoleh untuk aktiva, sehingga laba bersih yang diperoleh bank akan semakin kecil (Almunawwaroh, 2017).

Berlandasarkan pada Peraturan Otoritas Jasa Keuiangan No.16/POJK.03/2014 mengenai penilaian kualitas aset produktif pada Bank Umum Syariah dan Unit Usaha Syariah, bank wajib melakukan penanaman dan menyediakan dana dengan prisip kehati-hatian yang berlandaskan syariah. Pihak direksi akan melaksanakan prinsip kehati-hatian tersebut dengan cara menilai, memonitoring dan mengambil tindakan untuk menjaga kualitas aset agar baik.

\section{Dana Pihak Ketiga}

Dana pihak ketiga dapat diartikan sebagai dana masyarakat yang dapat berupa giro, tabungan, dan dana deposito berjangka (Kusumayanti \& Jati, 2014). Dana pihak ketiga merupakan dana yang didapat dari masyarakat dalam bentuk perorangan, perusahaan, pemerintahan, rumah tangga, dan lainlain dalam satuan rupiah maupun valas. Bank dapat memberikan berbagai simpanan kepada masyarakat supaya dapat memperoleh dana-dana dari masyarakat yang luas, meliputi masyarakat individu, maupun badan usaha (Nirwana \& Septiarini, 2015). Bank memiliki beberapa jenis menghimpun dana yaitu, giro wadiah, tabungan wadiah, tabungan mudharabah, deposito mudharabah (Kasmir, 2015). Umumnya dana yang dihimpun oleh perbankan dari masyarakat akan digunakan untuk pendanaan aktivitas sektor riil melalui penyaluran kredit (Husaeni, 2017).

Masyarakat mempunyai kebutuhan akan suatu lembaga keuangan, yaitu yang dapat menyimpankan uang nasabah dalam jumlah yang begitu besar. Setelah itu, harta yang disimpankan oleh nasabah kepada lembaga keuangan dapat diproduktifkan lagi oleh bank dalam bentuk penyaluran pembiayaan 
bagi nasabah yang memerlukan sejumlah modal. Sehingga pada hal ini antara bank maupun nasabah memiliki iktikad tolong-menolong sehingga kerberkahan dan kebaikan akan didapatkan. Semakin tinggi rasio dana pihak ketiga ini, maka semakin baik tingkat kepercayaan masyarakat terhadap bank yang bersangkutan (Lukitasari \& Kartika, 2015).

\section{Liabilitas}

Menurut PSAK liabilitas merupakan kewajiban terkait kejadian pada masa lalu yang cara menyelesaikannya dapat menyebabkan arus keluar. Menurut FSAB liabitas merupakan loyalitas manfaat ekonomi di masa kemudian yang timbul karena adanya kewajiban atau untuk mentransfer asset, penyediaan jasa kepada entitas lainnya di masa di masa berikutnya. Menurut SAK Kerangka Dasar Penyusunan Dan Penyajian Laporan Keuangan (2014, No. 49, b) Liabilitas merupakan utang perusahaan masa kini yang timbul dari peristiwa masa lalu, penyelesaiannya diharapkan mengakibatkan arus keluar dari sumber daya perusahaan yang mengandung manfaat ekonomik (Zahara \& Zannati, 2018).

Kewajiban merupakan utang dari suatu perusahaan yang digunakan untuk biaya berbagai kebutuhan perusahaan seperti transaksi yang menimbulkan kewajiban perusahaan untuk membayarkan kepada pihak lain. Munawir mendefinisikan utang merupakan kewajiban keuangan perusahaan kepada pihak terkait dan utang adalah sumber dana bagi suatu perusahaan yang asalnya dari kreditur.

Hutang merupakan suatu kewajiban (liabilitas). Maka liabilitas atau hutang merupakan kewajiban yang dimiliki oleh pihak perusahaan yang mendapat sumber dari dana eksternal baik yang berasal dari sumber suatu pinjaman perbankan, leasing, penjualan obligasi dan sejenisnya (Fahmi, 2017).

Berdasarkan rentang waktu, hutang dibagi menjadi dua jenis yaitu hutang jangka panjang dan hutang jangka pendek (Wardoyo, Putri, et al., 2022). Hutang jangka panjang adalah Kewaijiban perusaihaan yang mesti dipenuhi kepada pihak lainnya pada kurun waktu satu tahun lebih. Hutang 
jangaka pendek adalah Kewajiban perusahaan yang mesti dipenuhi kepada pihak lainnya pada kurun waktu normal, secara umum pada lebih kecil dari satu tahun maupun satu tahun dimulai dari disusunnya neraca, atau utang yang jatuh tempo termasuk dalam siklus akuntansi saat ini (Purwanti et al., 2021)

Dalam perspektif islam Menurut M.Quraish Shihab pada Q.S Al-Baqarah ayat 282 dikenal dengan oleh para iulama dengan ayat Al-Mudayamah atau ayat utang piutang, dimana ayat ini tentang anjuran, untuk wajib menulis utang piutang dan diperlihatkan dihadapan pihak ketiga yang dapat dapat diberi kepercayaan, serta sangat diperlukannya menulis utang walaupun jumlahnya sedikit disertai dengan waktunya. Bank yang biasanya diartikan dengan lembaga keuangan di mana kegiatannya menghimpun dana serta mendistribusikan dana tersebut kembali kemasyarakat.

5. Bank Syariah

Bank syariah menggerakkan aktivitas operasionalnya didasarkan prinsip syariah sebagai lembaga intermediasi yang menghimpun dan mendistribusikan dana dari dan ke masyarakat dengan menerapkan prinsip non bunga atau prinsip bagi hasil (Djamil, 2013)

Bank syariah terdiri dari Bank Umum Syariah (BUS) yang memberikan bantuan terkait pembayaran, Unit Usaha Syariah (UUS) yaitu unit kerja kantor pusat bank umum konvensional dan Bank Pembiiayaan Rakyat Syariah (BPRS) yang tidak menyediakan lalu lintas proses bayaran (Soemitra, 2009).

Dalam menjalankan kegiatannya, bank syariah berpedoman pada AlQuran dan hadits. Allah SWT mengharamkan riba, dijelaskan dalam Q.S An.Nisa ayat 29:

Artiinya: Hai orang-orang yang beriman, janganlah kamu saling memakan harta sesamamu dengan jalan yang batil, kecuali dengan jalan perniagaan yang berlaku dengan suka sama suka di antara kamu. Dan janganlah kamu membunuh dirimu; sesungguhnya Allah adalah Maha Penyayang kepadamu. 
Ayat diatas telah memaparkan bahwa Allah SWT mengaharamkan untuk mengkonsumsi, dan mengambil harta milik orang dengan cara bathil. Transaksi atas harta milik orang hendaknya dilakukan dengan jalan perdagangan langsung antara kedua pihak, saling ikhlas dan saling ridho.

\section{Laporan Keuangan}

Suatu informasi yang menjelaskan bentuk posisi keuangan berada dalam suatu perusahaan serta informasinya digunakan untuk memberikan penggambaran terkait pencapaian kinerja perusahaan. Laporan keuangan merupakan hal yang terpenting dalam memberikan informasi atas pencapaian suatu perusahaan. Sehingga, laporan keuangan diharapkan dapat memberikan bantuan bagi pembuat keputusan untuk membantu dalam proses pengambilan keputusan terkait keuangan

Bank Indonesia telah membuat peraturan mengenai cara pelaporan kondisi keuangan, bank syariah maupun konvensional. Aturan-aturan yang telah diberikan Bank Indonesia mencakup Pedoman Akuntansi Perbankan Indonesia yang berhubungan antara bank, akuntan publik, dan Bank Indonesia. Pancatatan keuangan idalam Islam sudah ada sejak peradaban islam dengan mendirikan Baitul Mal sebagai lembaga keuangan dan bendahara Negara yang menjamin kesejahteraan sosial. Allah SWT telah memberikan perintah untuk menggunakan catatan sebagai dokumen bukti suatu transaksi yang dilakukan tidak secara tunai. Prinsip umum pada operasional akuntansi Islam ada tiga, yaitu, prinsip pertanggungjawaban, prinsip keadilan, prinsip, prinsip kebenaran.

Tujuan dari laporan keuangan Menurut paragraf 30 KDPPLKS (Kerangka Dasar Penyusunan dan Penyajian Laporan Keuangan Syariah), mengatakan tujuan dari report keuangan yaitu memberikan informasi tentang posisi keuangan, kemampuan, dan juga perubahan kondisi keuangan pada sebuah entitas syariah yang memberikan manfaat untuk sebagian besar user dalam mengembalikan keputusan ekonomi. 


\section{METODOLOGI PENELITIAN}

Penelitian menggunakan metode kuantitatif ini diperlukan adanya sebuah hipotesis dan hasil uji yang dilakukan digunakan untuk menentukan tahapan selajutnya, seperti penentuan teknik analisa dan formula statistik yang digunakan. Penelitian kuantitatif ini dikatakan sebagai metode yang lebih merujuk kepada aspek pengukuran secara objektif terhadap fenomena sosial. Agar pengukuran dapat dilakukan, maka setiap fenomena sosial akan dijabarkan kedalam beberapa komponen masalah, variabel, serta indikator.

Setiap variabel yang telah ditentukan, dapat diukur dengan memberikan simbol berupa angka yang berbeda yang disesuaikan dengan informasi yang berkaitan dengan variabel yang digunakan. Dengan symbol dan angka yang digunakan, maka teknik perhitungan secara matematik dapat dilakukan sehingga dapat ditarik kesimpulan yang berlaku dalam suatu parameter. Tujuan yang mendasar dari metode kuantitatif ini yaitu dapat menjelaskan suatu masalah, tetapi dapat menghasilkan generalisasi.

Generalisasi merupakan kenyataan yang berupa kebenaran yang terjadi dalam suatu keadaan nyata tentang masalah yang diperkirakan akan berlaku pada suatu populasi. Generalisasi dapat dihasilkan dengan metode perkiraan atau metode estimasi yang dilakukan berdasarkan pengukuran terhadap keadaan yang nyata yang ruang lingkutnya lebih terbatas yang biasa dikenal dengan "sampel" peneltiian kuantitatif. Pengukuran yang dilakukan dalam penelitian ini merupakan bagian kecil dari populasi yang disebut dengan data penelitian.

Pada penelitian ini menggunakan data sekunder, menggunakan teknik pengumpulan dokumentasi. Metode ini membantu dalam proses pengambilan, pengumpulan, dan penyusunn informasi yang diangkat. Dokumentasi yang dibutuhkan yaitu report keuangan yang dipublikasi pada situs web resmi Bank Syariah Bukopin (Syafina, 2019) 


\section{HASIL DAN PEMBAHASAN}

Hasil Uji t-statistik untuk variabel Kualitas Aktiva Produktif menunjukkan bahwa nilai probability sebesar 0,0399<0.05, sedangkan untuk nilai $\mathrm{t}$ hitung $>\mathrm{t}$ tabel sebesar $(-2.145546>2.013287)$. Sehingga dapat ditarik kesimpulan bahwa variabel Kualitas Aktiva Produktif (KAP) berpengaruh secara negatif dan signifikan terhadap variabel Earning After Tax (EAT). Artinya, semakin tinggi nilai kualitas aktiva produktif maka Earning After Tax akan menurun. Karena pada penelitian ini tingginya jumlah atau rasio aktiva produktif yang bank miliki maka akan mengakibatkan biaya yang tidak produktif pula. Hal ini akan mengakibatkan tunggakan pembentukan PPAP, yang mana makin tinggi PPAP yang ditimbulkan maka akan mengganggu profitabilitas suatu bank.

(Wida, 2019) “Pengaruh Aset Produktif dan Dana Pihak Ketiga Terhadap Earning After Tax Bank Bni Syariah Kendari Periode 2014-2018" yang menyatakan bahwa Kualitas Aktiva Produktif berpengaruh negatif terhadap laba bersih pada Bank BNI Syariah Kediri periode 2014-2018. Hasil penelitian ini bertolak belakang dengan hasil penelitian yang dilakukan oleh (Ruslan, 2021) yang menyatakan bahwa Kualitas Aktiva Produktif Kredit berpengaruh secara signifikan dan positif terhadap laba setelah pajak (Earning After Tax). Hal ini menunjukkan bahwa semakin tinggi Kualitas Aktiva Produktif Kredit dari BPR akan semakin tinggi pula laba setelah pajak (Earning After Tax) yang dicapai oleh BPR. Selain itu, hasil penelitian oleh (Sugiyanti \& Sianturi, 2016) menyatakan bahwa struktur aktiva produktif tidak berpengaruh signifikan terhadap profitabilitas pada bank yang terdaftar di BEI.

Hasil Uji t-statistik untuk variabel Dana Pihak Ketiga menunjukkan bahwa nilai probability sebesar $0.6412>0.05$, sedangkan untuk nilai $\mathrm{t}$ hitung $<\mathrm{t}$ tabel sebesar $0.470621<2.013287$. Kesimpulannya bahwa variabel Dana Pihak Ketiga (DPK) tidak mempunyai pengaruh terhadap variabel Earning After Tax (EAT). Karena dana pihak ketiga mengalami penaikan setiap bulannya, tetapi biaya operasional yang harus dibayarkan oleh bank juga bisa mengalami 
kenaikan, jadi dana pihak ketiga yang digabungkan dari masyarakat tersebut digunakan untuk menutupi biaya operasional tersebut. Sehingga, dana suatu bank tidak bisa menjadikan dana pihak ketiga sebagai acuan dalam memperoleh laba.

Hasil penelitian ini sejalan dengan Wahyu Widianingsih (2020) “ Pengaruh Jumlah Penyaluran Pembiayaan Bagi Hasil, Dana Pihak Ketiga (DPK) Dan Non Performing Financing (NPF) Terhadap Earning After Tax (EAT) Bank Umum Syariah Di Indonesia Periode 2016-2018" yang menyatakan bahwa Dana Pihak Ketiga tidak berpengaruh terhadap Earning After Tax (EAT). Hasil penelitian ini juga sejalan dengan hasil penelitian oleh (Astutiningsih \& Baskara, 2019) yang menyatakan bahwa Dana Pihak Ketiga (DPK) tidak berpengaruh signifikan terhadap Profitabilitas BPR di Kabupaten Badung selama periode 2014-2016. Adapun penelitian oleh (Kristiyanto, 2016) menyatakan bahwa Dana Pihak Ketiga (DPK) mempunyai hubungan negatif dan signifikan terhadap laba pada Bank Pembangunan Daerah di Indonesia. Namun, hasil penelitian ini berbeda dengan penelitian yang dilakukan oleh (Karunia, 2013) yang menyatakan bahwa Dana Pihak Ketiga (DPK) berpengaruh positif dan signifikan terhadap ROA. Dana Pihak Ketiga (DPK) semakin besar maka semakin tinggi ROA. Kondisi ini akan menguatkan persepsi masyarakat untuk menyimpan dananya di bank, dan secara teoritis masyarakat mempercayai bank, karena masyarakat menyerahkan uangnya untuk dikelola oleh bank.

Hasil uji t-statistik untuk variabel Liabilitas mengindikasikan bahwa nilai probability sebesar $0.818274>0.05$, sedangkan untuk nilai $\mathrm{t}$ hitung $>\mathrm{t}$ tabel sebesar $(-2.972161>2.013287)$. Sehingga dapat ditarik kesimpulan bahwa variabel Liabilitas berpengaruh secara negatif terhadap variabel Earning After Tax (EAT). Utang dapat dikatakan membawa keuntungan karena bunga yang dihasilkan sedikit. Dengan adanya bunga yang kecil, maka nantinya akan dapat meningkatkan laba pada suatu perusahaan. Namun dalam hasil penelitian ini semakin tinggi jumlah suatu hutang maka earning after tax pada bank syariah 
bukopin akan semakin menurun. Karena hasil penelitian ini menunjukkan hutang berpengaruh negatif dikarenakan hutang juga memiliki resiko pada suatu perusahaan.hutang memiliki biaya bunga yang fluktuatif, jika suatu perusahaan terlalu banyak menggunakan hutang, maka akan menyebabkan turunnya suatu laba dan menyebabkan kebangkrutan.

Hasil penelitian ini sejalan dengan penelitian oleh (Nurlita \& Pratiwi, 2020) yang menyatakan bahwa liabilitas jangka pendek tidak berpengaruh secara signifikan terhadap profitabilitas pada PT. Primarindo Asia Infrastruucture. Selain itu, hasil penelitian ini juga sejalan dengan penelitian oleh (Apdau et al., 2021) yang menyatakan bahwa utang berpengaruh negatif terhadap laba bersih pada PT Indocement Tunggal Prakasa tbk tahun 2021. Adapun hasil penelitian oleh (Zahara \& Zannati, 2018) menyatakan bahwa total hutang tidak berpengaruh dan tidak signifikan terhadap laba bersih. Namun, hasil penelitian ini bertolak belakang dengan penelitian oleh (Wardoyo, Aini, et al., 2022) yang menyatakan bahwa liabilitas berpengaruh secara positif terhadap profitabilitas. Artinya, apabila aset yang didapat dari liabilitas bertambah maka profitablitas pun bertambah. Kemampuan pembelian aset dari hutang yang tinggi untuk mendapat profitabilitas yang tinggi juga. Selain itu, penelitian lain oleh (Jashinta et al., 2018) yang menyatakan bahwa liabilitas lancar berpengaruh signifikan terhadap laba perusahaan. Liabilitas lancar digunakan untuk membiayai kegiatan usaha maupun untuk persediaan bahan baku perusahaan, sehingga kegiatan perusahaan bisa berjalan lancar dan mendapatkan pendapatan yang maksimal.

\section{KESIMPULAN}

Berdasarkan hasil pengolahan data maka kesimpulan hasil penelitian Secara Parsial Variabel Kualitas Aktiva Produktif (KAP) berpengaruh secara negatif dan signifikan terhadap Earning After Tax (EAT) pada Bank Syariah Bukopin periode 2018 -2020, secara Parsial variabel Dana Pihak Ketiga (DPK) tidak berpengaruh terhadap Earning After Tax (EAT) pada Bank Syariah 
Bukopin periode 2018 - 2020, secara Parsial Variabel Liabilitas berpengaruh secara negatif dan siginifikan terhadap Earning After Tax (EAT) pada Bank Syariah Bukopin periode 2018-2020, dan ecara simultan variabel Kualitas Aktiva Produktif (KAP), Dana Pihak Ketiga (DPK) dan Liabilitas berpengaruh signifikan terhadap Earning After Tax (EAT) pada Bank Syariah Bukopin 2018 2020.

\section{IMPLIKASI PENELITIAN}

Implikasi pada penelitian ini yaitu Earning After Tax yang mengalami peningkatakan, sesuai dengan penyebabnya yaitu jika makin tinggi laba maka suatu perusahaan akan makin fleksibel pula untuk melaksanakan setiap proses kegiatan yang ada di dalam perusahaan tersebut.

\section{REFERENSI}

Almunawwaroh, M. (2017). Analisis Pengaruh Kecukupan Modal, Kualitas Aktiva Produktif dan Likuiditas Terhadap Kinerja Bank Umum Syariah di Indonesia. Jurnal Akuntansi, 12(1), 69-84.

Apdau, N. Z., Sutriyadi, R., \& Nasril. (2021). Pengaruh Utang Terhadap Laba Bersih PT Indocement Tunggal Prakasa Tbk Tahun 2021. Jurnal Lentera Akuntansi, 6(2), 149-158.

Astutiningsih, K. W., \& Baskara, I. G. K. (2019). Pengaruh CAR, Dana Pihak Ketiga, Ukuran Bank, Dan LDR Terhadap Profitabilitas Bank Perkreditan Rakyat. E-Jurnal Manajemen Universitas Udayana, 8(3), 1608-1636. https:// doi.org/10.24843/ejmunud.2019.v08.i03.p16

Dewi, N. T., \& Wisadha, I. G. S. (2015). Pengaruh Kualitas Aktiva Produktif, CAR, Leverage, dan LDR pada Profitabilitas Bank. E-Jurnal Akuntansi Universitas Udayana, 12(2), 295-312.

Djamil, F. (2013). Antonio, M Syafi'I. Bank Syariah Dari Teori ke Praktek. Jakarta: Gema Insani, 2001. Arifin, Muzayyin. Filsafat Pendidikan Islam. Jakarta: Bumi Aksara, 2005. Arikunto, Suharsimi. Prosedur Penelitian 
Suatu Pendekatan Praktik. Jakarta: PT Rineka Cipta, 2010. Jurnal Universitas Gunadarma, 7(05).

Fahmi, I. (2017). Analisis laporan keuangan.

Husaeni, U. A. (2017). Analisis Pengaruh Dana Pihak Ketiga Dan Non Performing Financing Terhadap Return On Asset Pada BPRS Di Indonesia. Equilibrium: Jurnal Ekonomi Syariah, 5(1), 1-16. https:// doi.org/10.32528/jmbi.v6i1.3538

Jashinta, N., Yuniarti, E., \& Ridwansyah, E. (2018). Pengaruh Liabilitas Lancar Terhadap Laba Perusahaan pada PT Adhi Karya. Karya Ilmiah Mahasiswa Politeknik Negeri Lampung, 1-7.

Karunia, C. (2013). Analisis Pengaruh Rasio Capital, Asset Quality Dan Liquidty Terhadap Kinerja Keuangan Pada Sektor Perbankan Yang Terdaftar Di Bursa Efek Indonesia (Bei) Periode 2007-2011. Calyptra: Jurnal Ilmiah Mahasiswa Universitas Surabaya, 2(1), 1-17.

Kasmir, D. (2015). Dasar-Dasar Perbankan Edisi Revisi 2014. Jakarta: Rajawaloi Pers.

Kristiyanto, S. (2016). Analisis Pengaruh Aktiva, Dana Pihak Ketiga dan Kredit Terhadap Profitabilitas Bank Pembangunan Daerah di Indonesia Periode Tahun 2009 - 2014. E-Jurnal Spirit Pro Patria, 2(1).

Kusumayanti, A. D., \& Jati, I. K. (2014). Pengaruh Aktiva Produktif, Dana Pihak Ketiga Dan Letak Geografis Pada Kinerja Operasional LPD. E-Jurnal Akuntansi Universitas Udayana, 9(3), 617-632.

Lailatus, S., SE, M. M., Ita Rahmawati, S. E., \& Ade Ira Yulia Santi, S. M. (2020). Implementasi Pengukuran Capital Asset Pricing Model (CAPM) dan Earning Per Share (EPS) serta Pengaruhnya terhadap Harga Saham. LPPM Universitas KH. A. Wahab Hasbullah.

Lukitasari, Y. P., \& Kartika, A. (2015). Analisis Pengaruh Dana Pihak Ketiga, BOPO, CAR, LDR Dan NPL Terhadap Kinerja Keuangan Pada Sektor Perbankan Yang Terdaftar Di Bursa Efek Indonesia. Jurnal Ilmiah Infokam, 11(4), 28-39. 
Nirwana, L. P., \& Septiarini, D. F. (2015). Pengaruh Pertumbuhan Dana Pihak Ketiga Terhadap Laba Perbankan Syariah di Indonesia. Jurnal Ekonomi $\begin{array}{llll}\text { Syariah Teori Dan } & \text { 642-657. }\end{array}$ https:// doi.org/10.20473/vol2iss20158pp642-657

Nurlita, S., \& Pratiwi, A. (2020). Pengaruh Liabilitas Dan Ekuitas Terhadap Profitabilitas Pada PT Primarindo Asia Infrastructure Tbk. JUIMA: Jurnal Ilmu Manajemen, 10(2), 36-44.

Purwanti, L., Prastiwi, A., \& Atmini, S. (2021). Akuntansi Keuangan. Universitas Brawijaya Press.

Rohim, N., Askandar, N. S., \& Junaidi. (2017). Pengaruh Aktiva Produktif, Dana Pihak Ketiga, Dan Non Performing Loan Terhadap Kinerja Operasional Bank Umum Konvensional Yang Terdaftar Di Bursa Efek Indonesia Periode 2013-2015. Jurnal Ilmiah Riset Akuntansi, 6(05), 58-74. https:// doi.org/10.21512/bbr.v2i1.1161

Ruslan, A. (2021). Pengaruh Loan To Deposit Ratio Dan Kualitas Aktiva Produktif Terhadap Pencapaian Laba Bank Perkreditan Rakyat (BPR) Di Indonesia. Al-Iqtishad: Jurnal Ekonomi, 1(1), 47-71.

Sarmo, S., Muttaqillah, \& Effendi, H. A. (2019). Pengaruh Earnings After Tax, Current Ratio, Debt to Equity Ratio terhadap Deviden Payout Ratio. Valid: Jurnal Ilmiah, 16(1), 86-98.

Soemitra, A. (2009). Bank dan lembaga keuangan syariah. Kencana Prenada Media Group.

Sugiyanti, \& Sianturi, H. (2016). Analisis Pengaruh Kualitas Aktiva Produktif Dan Kredit Bermasalah Terhadap Profitabilitas (Studi Empiris Pada Bank Pemberi Kredit Yang Terdaftar Di BEI). Jurnal Ilmiah Akuntansi Dan Ekonomi, 1(1), 29-42.

Sunarto, N., \& Supriati, S. (2017). Pengaruh Kualitas Aktiva Produktif Terhadap Return on Assets (Studi Pada Bank Umum Yang Listing Di Bursa Efek Indonesia Tahun 2006-2010 ). Inovbiz: Jurnal Inovasi Dan Bisnis, 5(1), 3-11. https://doi.org/10.35314/inovbiz.v5i1.164 
Syafina, L. (2019). Metode Penelitian Akuntansi Pendekatan Kuantitatif. UINSU PRESS.

Wardoyo, D. U., Aini, H. N., \& Kusworo, J. S. P. (2022). Pengaruh Liabilitas Dan Struktur Modal Terhadap Profitabilitas (Studi Empiris Pada Perusahaan Sub Sektor Makanan dan Minuman Yang Terdaftar di Bursa Efek Indonesia Periode 2019-2020). Jurnal Publikasi Ilmu Ekonomi Dan Akuntansi, 2(1), 23-29.

Wardoyo, D. U., Putri, E. A., \& Hasani, N. A. (2022). Pengaruh Total Liabilitas dan Total Ekuitas terhadap Laba. Syntax Idea, 4(2), 317-327.

Wida. (2019). Pengaruh Aset Produktif Dan Dana Pihak Ketiga Terhadap Earning After Tax Bank Bni Syariah Kendari Periode 2014-2018. IAIN Kendari.

Zahara, A., \& Zannati, R. (2018). Pengaruh Total Hutang, Modal Kerja, Dan Penjualan Terhadap Laba Bersih Pada Perusahaan Sub Sektor Batu Bara Terdaftar Di BEI. Jurnal Riset Manajemen Dan Bisnis, 3(2), 155-164.

$\underline{\text { www.ojk.go.id }}$

$\underline{\text { www.syariahbukopin.go.id }}$ 